\title{
MEASURING SUCCESSFUL LEADERSHIP VIA AN ECONOMETRIC MODEL - A CASE OF SONY IN JAPAN
}

\section{NGUYEN DUY DAT, BUI HUU DUC \& HOANG CAO CUONG}

Thuongmai University Hanoi Vietnam

\begin{abstract}
Among Japanese famous brand names and products is Sony and its great products. Sony has made it more and more popular not only by bringing to the market high quality products, but also by technical inventions. The firm has made very positive contributions to the overall achievements of the technology industry. Movement of net profit in big firms such as Sony will reflect the business health of technology system and the whole economy. Good business management requires us to consider the impacts of multi macro factors on net profit, and it contributes to promoting business plan and economic policies for economic growth and stabilizing macroeconomic factors. The results of quantitative research, in a seven factor model, show that the increase in inflation, GDP (increasing too much) and lending rate and reducing risk free rate has a significant effect on reducing Sony net profit with the highest impact coefficient, the second is decreasing the exchange rate. This research finding and recommended policy also can be used as reference in policy for technology system in many developing countries.

KEYWORDS: Sony Net Profit; Stock Price; GDP Growth; Inflationary; Cost; Market Interest Rate JEL: M21, N1
\end{abstract}

Received: Jun 08, 2020; Accepted: Jun 28, 2020; Published: Aug 28, 2020; Paper Id.: IJMPERDJUN2020926

\section{INTRODUCTION}

Sony in Japan maintained a higher growth rate than the industry average on all indicators of scale, quality, efficiency, and labor productivity.

Japanese manufacturers have paid attention to customers, always creating trust for their customers and therefore consumers, anywhere in the world also love to use more Japanese goods.

In the context that GDP growth in Japan has been stable during 2014-2019, it is necessary to evaluate impacts of seven (7) internal and external macro economic factors on Sony performance, esp. Firm net profit. From these analytical results, we could suggest bank and government policies to encourage and stabilize the growth of technology system and stock market.

Looking at the below chart, we find out that Sony net profit moves in the same trend with cost and GDP growth, although it fluctuates in a smaller range. 


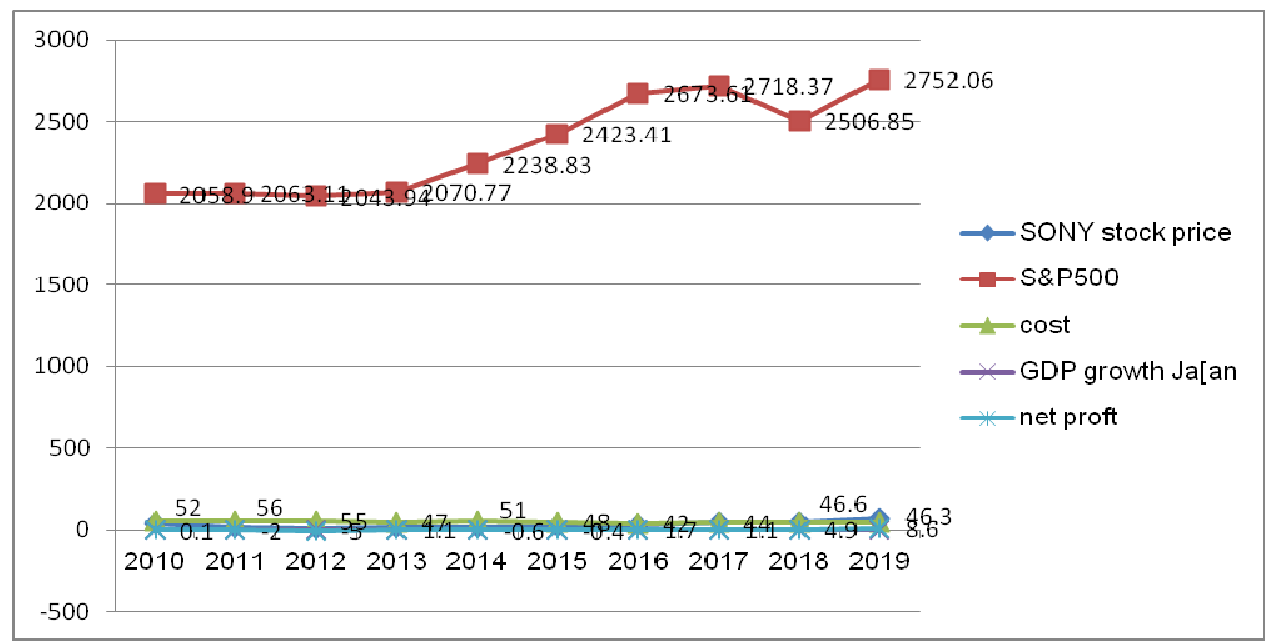

Figure 1

This study will calculate and figure out the impacts of seven (7) macro economic factors such as inflation, GDP growth, market interest rate, net sale, cost, S\&P500 on Sony net profit.

The paper is organized as follows: after the introduction it is the research issues, literature review and methodology. Next, section 3 will cover methodology and data and section 4 presents main research findings/results. Section 5 gives us some discussion and conclusion and policy suggestion will be in the section 6 .

\section{BODY OF MANUSCRIPT}

\section{Research Issues}

The scope of this study will cover:

- Issue 1: What are the correlation and relationship among many economic factors: Sony net profit, stock price, interest rate, cost, inflation, S\&P 500 and GDP growth?

- Issue 2: What are the impacts of above 7 macro economic factors on Sony net profit?

- Issue 3: Based on above discussion, we recommend some solutions regarding to technology management in incoming period.

This paper also tests two (2) below hypotheses:

- Hypothesis 1: An increase in lending rate will make Sony net profit declines.

- Hypothesis 2: An increase in inflation can increase pressure in Sony net profit.

\section{Literature Review}

Lina (2012) indicated that both the change of inflation rate and the growth rate of money supply (M2) are positive but insignificant to the banking industry stock return, the exchange rate is positive and significant to banking industry stock return and interest rate is negative and significant to banking industry stock return. Next, Sadia and Noreen (2012) found out exchange rate, and Short term Interest Rate have significant impact on Banking index. Macroeconomic variables like Money Supply, Exchange Rate, Industrial Production, and Short Term Interest Rate affects the banking index negatively where as Oil prices has a positive impact on Banking index. 
Manisha and Shikha (2014) stated that Exchange rate, Inflation, GDP growth rate affect banking index positively whereas Gold prices have negative impact on BSE Bankex but none of them have significant impact on Bankex. Then, Winhua and Meiling (2014) confirmed that macroeconomic do have a substantial influence to the earning power of commercial banks.

Krishna (2015) investigated the nature of the causal relationships between stock prices and the key macro economic variables in BRIC countries. The empirical evidence shows that long-run and short-run relationship exists between macro economic variables and stock prices, but this relationship was not consistent for all of the BRIC countries. And Kulathunga (2015) suggested that all macroeconomic factors influence the stock market development. More precisely, volatile inflation rate and exchange rate together with higher deposit rate have curtailed the stock market development in Sri Lanka. Moreover, positive optimism created by the economic growth and the stock market performance during the previous periods tend to enhance stock market performance. Moreover, Duy (2015) mentioned through the evolution of interest rates and the VNI could see that the relationship between these two variables in the period 2005-2014 is the opposite. This relationship is shown in specific periods of the year the stock market proved quite sensitive to interest rates. When interest rates are low or high but the bearish stock market rally, and vice versa when the high interest rates the stock market decline.

Last but not least, Quy and Loi (2016) found that 3 economic factors (inflation rate, GDP growth rate, and exchange rate) impact significantly on real estate stock prices; but the relationship between 10-year Government bond yield and trading volume, and real estate stock prices was not found. Ahmad and Ramzan (2016) stated the macroeconomic factors have important concerns with stocks traded in the stock market and these factors make investors to choose the stock because investors are interested to know about the factors affecting the working of stock to manage their portfolios. Abrupt variations and unusual movements of macroeconomic variables cause the stock returns to fluctuate due to uncertainty of future gains.

Until now, many researches have been done in this field, however, they just stop at analyzing internal macroeconomic factors on stock price.

Within the scope of this paper, we measure impacts of both internal and external macro factors on Sony net profit and suggest policies for bank system, government, Ministry of Finance, State Bank and relevant government bodies. We also analyze data throughout time series from 2014-2019.

\section{METHODOLOGY AND DATA}

This research paper establishes correlation among macro economic factors by using an econometric model to analyze impacts of seven (7) macro economic factors in Japan such as: GDP growth, inflation, interest rate, cost,... on Sony net profit.

In this research, analytical method is used with data from the economy such as inflation in Japan and market interest rate, GDP growth rate, SP500. Data are included from 2014 -2019 with semi-annual data (10 observations in total). Data is estimated based on exchange rate and lending interest rates of commercial banks. S\&P 500 index data is from USA Stock exchange, data source (inflation, GDP) is from Bureau of Statistics. Beside, econometric method is used with the software Eview. It will give us results to suggest policies for businesses and authorities. 
We build a regression model with Eview software to measure impacts of factors. Sony net profit is a function with 7 variables as follows:

$Y($ Sony net profit $)=f(x 1, x 2, x 3, x 4, x 5, \times 6, x 7)=a x 1+b x 2+c x 3+d x 4+\operatorname{ex} 5+f \times 6+g x 7+k$

With: $x 1$ : GDP growth rate $(g), x 2$ : inflation, $x 3$ : net sale, $x 4$ : lending rate, $x 5$ : risk free rate (Rf), x6: cost; $x 7$ : S\&P500

Beside, this paper also uses analytical and general data analysis method to measure and generate comments on the results, then suggest policies based on these analyses.

\section{MAIN RESULTS}

\section{General Data Analysis}

First of all, the below chart 1 shows us that $\mathrm{Y}$ has a negative correlation with cost:

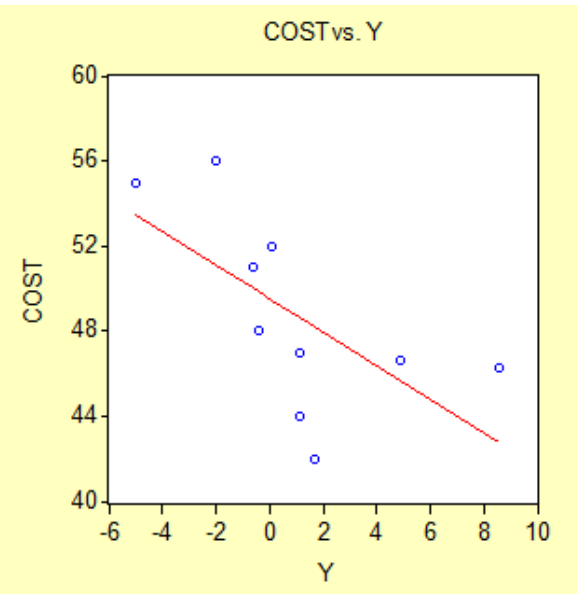

Chart 1: Net Profit (Y) vs. Cost (C).

Next we find out that, based on the below scatter chart, Y (net profit) has slightly positive correlation with inflation (CPI).

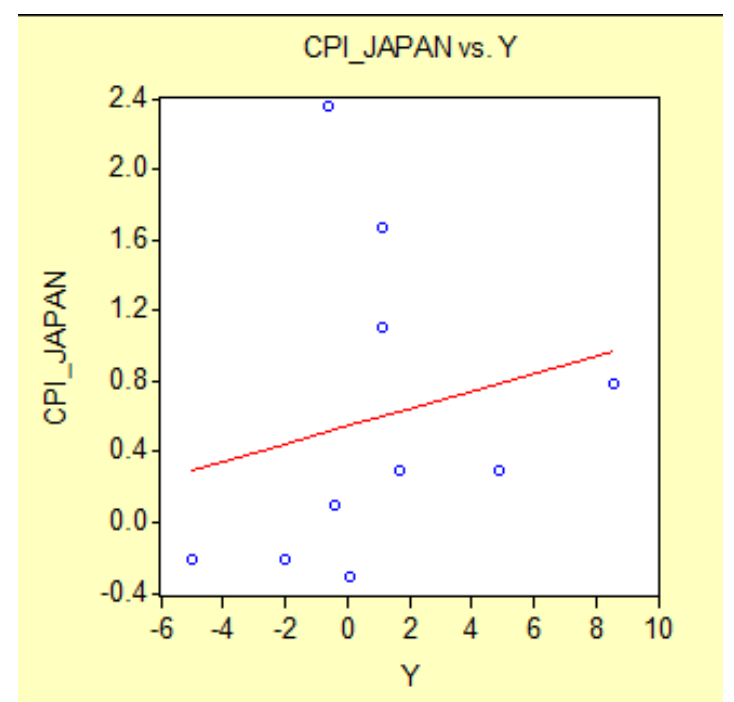

Chart 2: Sony Net Profit (Y) vs. Inflation (CPI). 
Looking at the below chart 3, we also recognize that Sony net profit (Y) and GDP growth have negative correlationship.

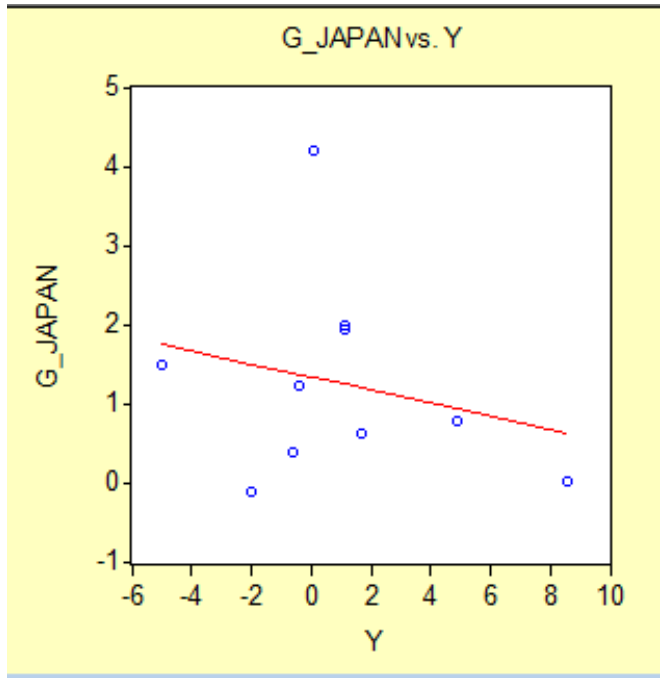

Chart 3: Y vs. GDP Growth.

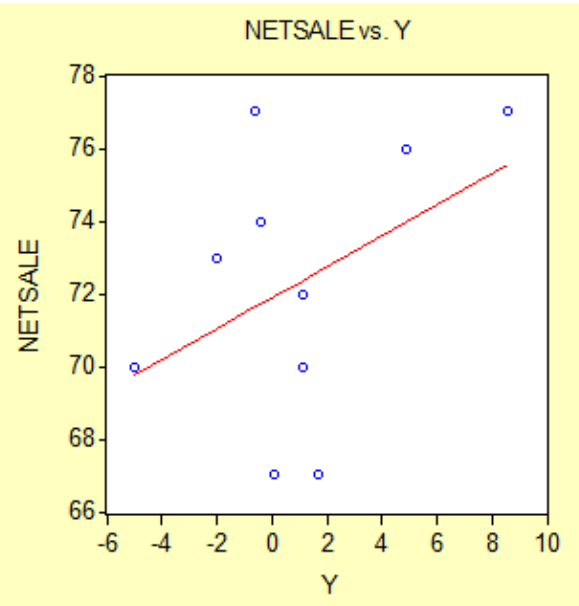

Chart 4: Y vs. Sale.

We see that, Sony net profit (Y) and sale have positive correlation:

On the other hand, we could see statistical results with Eview in the below table with 8 variables:

Table 1: Statistics for Macro and Micro Economic Factors

\begin{tabular}{|c|c|c|c|c|c|c|c|c|c|}
\hline & $\begin{array}{c}\text { Net } \\
\text { profit }\end{array}$ & Net sales & Cost & $\begin{array}{c}\text { SONY } \\
\text { stock } \\
\text { price }\end{array}$ & $\begin{array}{c}\text { Inflation } \\
\text { Japan }\end{array}$ & $\begin{array}{c}\text { Lending } \\
\text { rate } \\
\text { Japan }\end{array}$ & $\begin{array}{c}\text { GDP } \\
\text { growth - } \\
\text { US }\end{array}$ & $\begin{array}{c}\text { Inflatio } \\
\text { n US } \\
\text { (CPI) }\end{array}$ & $\begin{array}{c}\text { S\&P500 } \\
\text { Mean }\end{array}$ \\
0.95 & 72.30 & 48.79 & 31.66 & 0.59 & 1.18 & 2.24 & 1.76 & 2354.99 \\
\hline Median & 0.6 & 72.5 & 47.5 & 26.32 & 0.3 & 1.165 & 2.23 & 1.825 & 2331.12 \\
\hline Maximum & 8.6 & 77 & 56 & 68 & 2.36 & 1.55 & 2.92 & 2.96 & 2752.06 \\
\hline Minimum & -5 & 67 & 42 & 11.2 & -0.31 & 0.96 & 1.55 & 0.73 & 2043.94 \\
\hline $\begin{array}{c}\text { Standard } \\
\text { dev. }\end{array}$ & 3.709 & 3.773 & 4.590 & 17.602 & 0.888 & 0.217 & 0.485 & 0.680 & 294.931 \\
\hline
\end{tabular}


Looking at the above table, we recognize that standard deviation of stock price and SP500 are the highest values.

Whereas standard deviation of GDP growth and lending rate are the lowest values.

If we want to see correlation matrix of these 8 macro variables, Eview generate the below result in table 2:

Table 2: Correlation Matrix for 8 Macro-Economic Variables (GDP Growth, Inflation, Market Interest Rate, Net Sale, Cost and Sony Net Profit)

\begin{tabular}{|c|c|c|c|c|c|c|c|c|c|c|}
\hline \multicolumn{11}{|c|}{ Correlation Matrix } \\
\hline & $\mathrm{Y}$ & NETSALE & STOCKPRICE & SP500 & R_JAPAN & G_JAPAN & CPI_JAPAN & $\mathrm{CPI}$ & COST & G \\
\hline $\mathrm{Y}$ & 1.000000 & 0.418903 & 0.895459 & 0.830240 & -0.601516 & -0.238693 & 0.209457 & 0.204226 & -0.633707 & 0.143229 \\
\hline NETSALE & 0.418903 & 1.000000 & 0.295740 & 0.459264 & -0.276997 & -0.630437 & 0.445824 & -0.152122 & 0.067565 & 0.363764 \\
\hline STOCKPRICE & 0.895459 & 0.295740 & 1.000000 & 0.812740 & -0.533837 & -0.083095 & 0.014404 & 0.283042 & -0.511029 & 0.276965 \\
\hline \begin{tabular}{|l|} 
SP500 \\
\end{tabular} & 0.830240 & 0.459264 & 0.812740 & 1.000000 & -0.890764 & -0.410502 & 0.369848 & 0.093920 & -0.739071 & 0.173181 \\
\hline R_JAPAN & -0.601516 & -0.276997 & -0.533837 & -0.890764 & 1.000000 & 0.428597 & -0.360615 & 0.017708 & 0.839620 & -0.112817 \\
\hline G_JAPAN & -0.238693 & -0.630437 & -0.083095 & -0.410502 & 0.428597 & 1.000000 & -0.202767 & -0.307192 & 0.058494 & 0.276697 \\
\hline CPI_JAPAN & 0.209457 & 0.445824 & 0.014404 & 0.369848 & -0.360615 & -0.202767 & 1.000000 & -0.387468 & -0.316100 & -0.036399 \\
\hline $\mathrm{CPI}$ & 0.204226 & -0.152122 & 0.283042 & 0.093920 & 0.017708 & -0.307192 & -0.387468 & 1.000000 & 0.047461 & -0.612037 \\
\hline COST & -0.633707 & 0.067565 & -0.511029 & -0.739071 & 0.839620 & 0.058494 & -0.316100 & 0.047461 & 1.000000 & 0.007991 \\
\hline G & 0.143229 & 0.363764 & 0.276965 & 0.173181 & -0.112817 & 0.276697 & -0.036399 & -0.612037 & 0.007991 & 1.000000 \\
\hline
\end{tabular}

The above table 2 shows us that correlation among 8 macro variables. An increase in exchange rate and decrease in lending rate might lead to an increase in Sony net profit. It also indicates that correlation between Sony net profit (Y) in Japan and stock price and S\&P 500 in the US (0.89 and 0.83) is higher than that between Y and lending rate (-0.6) or between Y and CPI (0.2).

The below table 3 shows us that covariance matrix among 8 macro economic variables. Sony net profit (Y) has a negative correlation with GDP growth and lending rate but has a positive correlation with CPI, and stock price.

Hence, an increase in inflation may have slight positive impact on Sony net profit.

Table 3: Covariance Matrix for 8 Macro Economic Variables

\begin{tabular}{|c|c|c|c|c|c|c|c|c|c|c|}
\hline \multicolumn{11}{|c|}{ Covariance Matrix } \\
\hline & $\mathrm{Y}$ & NETSALE & STOCKPRICE & SP500 & R JAPAN & G JAPAN & CPI JAPAN & $\mathrm{CPI}$ & COST & G \\
\hline $\mathrm{Y}$ & 12.37850 & 5.275000 & 52.61010 & 1756.382 & -0.435900 & -1.012395 & 0.620850 & 0.463350 & -9.708500 & 0.232000 \\
\hline NETSALE & 5.275000 & 12.81000 & 17.67560 & 988.3674 & -0.204200 & -2.720150 & 1.344300 & -0.351100 & 1.053000 & 0.599400 \\
\hline STOCKPRICE & 52.61010 & 17.67560 & 278.8555 & 8160.606 & -1.836132 & -1.672783 & 0.202638 & 3.047924 & -37.15902 & 2.129304 \\
\hline SP500 & 1756.382 & 988.3674 & 8160.606 & 361545.2 & -110.3189 & -297.5591 & 187.3542 & 36.41678 & -1935.071 & 47.94057 \\
\hline R JAPAN & -0.435900 & -0.204200 & -1.836132 & -110.3189 & 0.042424 & 0.106422 & -0.062576 & 0.002352 & 0.753040 & -0.010698 \\
\hline G JAPAN & -1.012395 & -2.720150 & -1.672783 & -297.5591 & 0.106422 & 1.453291 & -0.205936 & -0.238809 & 0.307055 & 0.153569 \\
\hline CPI JAPAN & 0.620850 & 1.344300 & 0.202638 & 187.3542 & -0.062576 & -0.205936 & 0.709769 & -0.210503 & -1.159610 & -0.014118 \\
\hline $\mathrm{CPI}$ & 0.463350 & -0.351100 & 3.047924 & 36.41678 & 0.002352 & -0.238809 & -0.210503 & 0.415841 & 0.133270 & -0.181704 \\
\hline COST & -9.708500 & 1.053000 & -37.15902 & -1935.071 & 0.753040 & 0.307055 & -1.159610 & 0.133270 & 18.96090 & 0.016020 \\
\hline G & 0.232000 & 0.599400 & 2.129304 & 47.94057 & -0.010698 & 0.153569 & -0.014118 & -0.181704 & 0.016020 & 0.211956 \\
\hline
\end{tabular}

\section{Regression Model and Main Findings}

In this section, we will find out the relationship between eight macro economic factors and net profit.

Scenario 1: Regression model with single variable: analyzing impact of cost (c.o) on Sony Net profit (Y)

Note: C: constant

Using Eview gives us the below results: 


\begin{tabular}{|c|c|c|c|c|}
\hline $\begin{array}{l}\text { Dependent Variable } \\
\text { Method: Least Squa } \\
\text { Date: } 02 / 26 / 20 \text { Tim } \\
\text { Sample: } 110 \\
\text { Included observation }\end{array}$ & $\begin{array}{l}13: 13 \\
10\end{array}$ & & & \\
\hline Variable & Coefficient & Std. Error & t-Statistic & Prob. \\
\hline $\cos T$ & -0.512027 & 0.220984 & -2.317034 & 0.0491 \\
\hline C & 25.93182 & 10.82466 & 2.395623 & 0.0435 \\
\hline R-squared & 0.401585 & Mean depe & dent var & 0.950000 \\
\hline Adjusted R-squared & 0.326783 & S.D. depen & ent var & 3.708624 \\
\hline S.E. of regression & 3.042918 & Akaike info & criterion & 5.240368 \\
\hline Sum squared resid & 74.07482 & Schwarz cr & erion & 5.300885 \\
\hline Log likelihood & -24.20184 & F-statistic & & 5.368645 \\
\hline Durbin-Watson stat & 0.786910 & Prob(F-stat & tic) & 0.049146 \\
\hline
\end{tabular}

Hence, $\mathrm{Y}=-0.5 *$ cost $+25.9, \mathrm{R}^{2}=0.4 \mathrm{SER}=3.04$

Within the range of 10 observations (2014-2019) as described in the above scatter chart 1 , coefficient -0.5 , when cost increases, Sony net profit will decrease.

Scenario 2 - Regression model with 2 variables: analyzing impact of Inflation (CPI) on Net profit (Y):

Running Eview gives us below results:

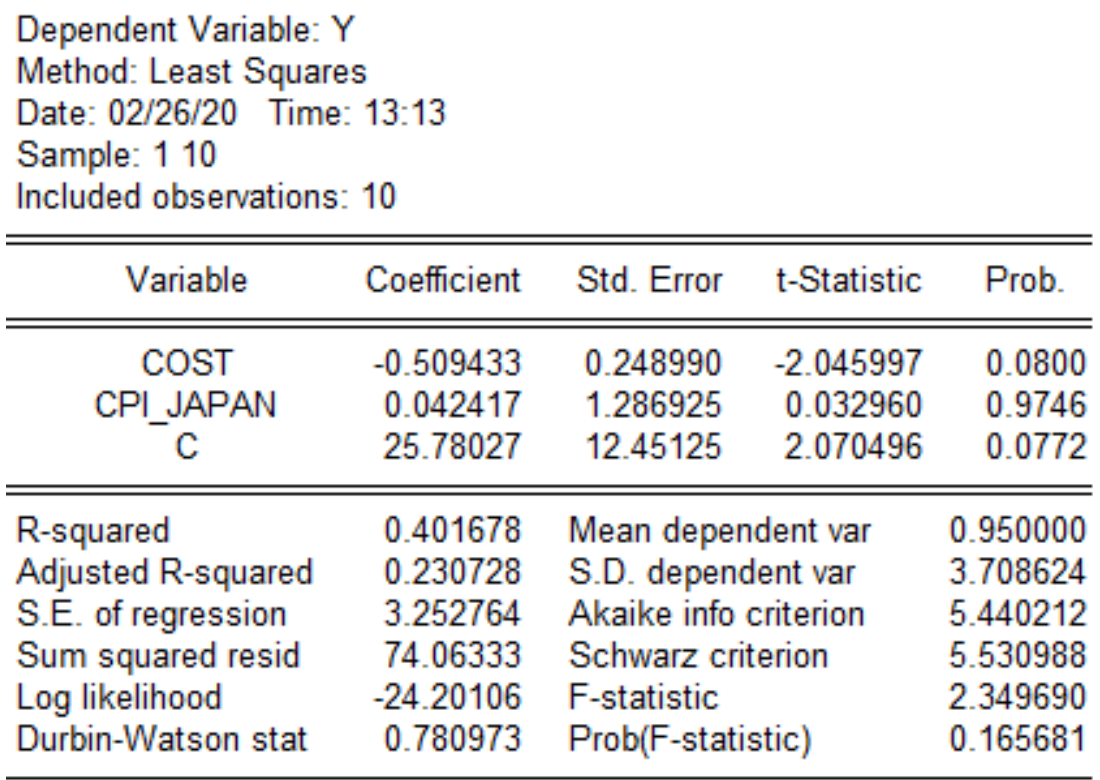

Therefore, $\mathrm{Y}=-0.5 *$ cost $+0.04 * \mathrm{CPI}+25.7, \mathrm{R}^{2}=0.4, \mathrm{SER}=3.25$

Hence, this equation shows us Sony net profit has a positive correlation with CPI and negative relationship with cost. Esp., it is more negatively affected by cost.

Scenario 3 - Regression model with 3-7 variables: adding factors into the above model 


\begin{tabular}{|l|c|c|c|c|}
\hline \multicolumn{5}{|c|}{ Table 4 } \\
\hline & \multicolumn{5}{|c|}{ Co efficient } \\
\hline & 3 Variables & 5 Variables & 6 Variables & 7 Variables \\
\hline Cost & -0.5 & -0.2 & -0.5 & -0.6 \\
\hline GDP Growth & -0.6 & -0.05 & -0.7 & -0.7 \\
\hline Net Sale & & 0.2 & 0.3 & 0.3 \\
\hline Stock Price & & 0.1 & 0.2 & 0.2 \\
\hline Lending Rate & & & & 5.3 \\
\hline SP500 & & & -0.006 & -0.003 \\
\hline CPI & -0.13 & -0.02 & 0.5 & 0.2 \\
\hline
\end{tabular}

Scenario 4 - regression model with 8 macro variables: adding GDP growth US onto the above model.

Running Eviews gives us results:

Dependent Variable: $Y$

Method: Least Squares

Date: 02/26/20 Time: 13:16

Sample: 110

Included observations: 10

\begin{tabular}{cclll}
\hline \hline Variable & Coefficient & Std. Error & t-Statistic & Prob. \\
\hline \hline COST & -0.549740 & 0.405461 & -1.355842 & 0.4046 \\
CPI_JAPAN & -0.443119 & 1.669288 & -0.265454 & 0.8348 \\
G_JAPAN & 0.709096 & 2.143195 & 0.330859 & 0.7966 \\
NETSALE & 0.863574 & 0.771428 & 1.119448 & 0.4642 \\
STOCKPRICE & 0.232283 & 0.170673 & 1.360983 & 0.4034 \\
SP500 & -0.006139 & 0.009201 & -0.667219 & 0.6254 \\
R_JAPAN & -5.477304 & 21.05174 & -0.260183 & 0.8380 \\
G & -3.070739 & 4.058999 & -0.756526 & 0.5877 \\
C & -16.65228 & 39.86964 & -0.417668 & 0.7481 \\
\hline \hline R-squared & 0.970447 & Mean dependent var & 0.950000 \\
Adjusted R-squared & 0.734025 & S.D. dependent var & 3.708624 \\
S.E. of regression & 1.912641 & Akaike info criterion & 3.632262 \\
Sum squared resid & 3.658194 & Schwarz criterion & 3.904588 \\
Log likelihood & -9.161308 & F-statistic & 4.104716 \\
Durbin-Watson stat & 2.472333 & Prob(F-statistic) & 0.365134 \\
\hline
\end{tabular}

$\mathrm{Y}=-0.5 * \cos t-0.4 * \mathrm{CPI}-5.4 * \mathrm{R}-0.4 * \mathrm{G}$ Japan $-3 *$ G_US $-0.006 * \mathrm{SP} 500+0.2 *$ STOCKPRICE +0.8*NETSALE-16,

$$
\mathrm{R}^{2}=0.97, \mathrm{SER}=1.9
$$

Therefore, we see impacts of 8 micro and macro factors, with the new variable: GDP growth US, the above equation shows that Sony net profit (Y) has negative correlation with cost, CPI, GDP growth, G_US, SP500, whereas it has positive correlation with stock price, net sale. We also recognize that GDP growth and lending rate, then CPI have the highest impact on net profit, while SP500 just has a slightly impact on net profit.

\section{DISCUSSION AND FURTHER RESEARCHES}

Through the regression equation with above 8 macroeconomic variables, this research paper used updated data from 20142019 to analyze the regression equation via Eview in order to show that an increase in lending rate and GDP growth has a 
significant impact on reducing Sony net profit $(\mathrm{Y})$ with the highest coefficient of impact, followed by an increase in CPI and increase in cost, then an increase in S\&P500, as well as a decrease in stock price.

Data are from observations in the past 10 years, it is partly based on the market economic rules, and the research results are also affected by socio-economic characteristics in Japan such as: efficiency of public investment, waste of public investment, enterprise bankruptcy, and investment in areas that increase GDP such as production, electricity, etc. or investing in healthcare, environment and education sectors. We have not yet considered the impact of these factors.

Beside, we can analyze impact of another macro factor, for example, deposit rate when we add this variable into our regression model of profit. Furthermore, we can add unemployment rate or public debt increase into our econometric model to measure the impact of these extra factors on net profit.

\section{CONCLUSIONS AND POLICY SUGGESTION}

Based on the above data analysis from our regression model, we would suggest the government, Ministry of Finance and State Bank consider to control inflation more rationally, i.e not increasing much and suitable with each economic development stage. Governmental bodies and bank system also need to apply macro policies to stimulate economic growth, however not increasing lending rate too much, together with credit, operational and market risk management, corporate governance and controlling bad debt.

Next, it is necessary to coordinate synchronously between the management and administration of commercial bank policies with fiscal policies, monetary policies (used as effective tools to stimulate bank stock price) and other economic development policies to limit the negative effects of lending rate.

Generally speaking, managing Sony net profit depends on many factors, so the government need to use fiscal policy combined with monetary policies and socio-economic policies to reduce unemployment and stimulate economic growth, toward a good stock price management.

\section{ACKNOWLEDGEMENTS}

I would like to take this opportunity to express my warm thanks to Board of Editors and my family, my colleagues, and brother in assisting convenient conditions for my research paper.

\section{REFERENCES}

1. Ahmad, N., \& Ramzan, M. (2016). Stock Market Volatility and Macroeconomic Factor Volatility, International Journal of Research in Business Studies and Management, 3(7), 37-44.

2. Arshad, Z., Ali, R. A., Yousaf, S., \& Jamil, S. (2015). Determinants of Share Prices of listed Commercial Banks in Pakistan, IOSR Journal of Economics and Finance, 6(2), 56-64.

3. Ayub, A., \& Masih, M. (2013). Interest Rate, Exchange Rate, and Stock Prices of Islamic Banks: A Panel Data Analysis, MPRA Paper No. 58871.

4. Cherif, R., \& Hasanov, F. (2012). Public Debt Dynamics: The Effects of Austerity, Inflation, and Growth Shocks, IMF Working paper WP/12/230.

5. Krishna, R.C. (2015). Macroeconomic Variables impact on Stock Prices in a BRIC Stock Markets: An Empirical Analysis, Journal of Stock \& Forex Trading, 4(2). 
6. Kulathunga, K. (2015). Macroeconomic Factors and Stock Market Development: With Special Reference to Colombo Stock Exchange, International Journal of Scientific and Research Publications, 5(8), 1-7.

7. Ihsan, H., Ahmad, E., Muhamad, I.H., \& Sadia, H. (2015). International Journal of Scientific and Research Publications, 5(8)

8. Jarrah, M., \& Salim, N. (2016). The Impact of Macroeconomic Factors on Saudi Stock Market (Tadawul) Prices, Int'l Conf. on Advances in Big Data Analytics.

9. Luthra, M., \& Mahajan, S. (2014). Impact of Macro factors on BSE Bankex, International Journal of Current Research and Academic Review, 2(2), 179-186.

10. Ndlovu, M., Faisal, F., Nil, G.R., \& Tursoy, T. (2018).The Impact of Macroeconomic Variables on Stock Returns: A Case of the Johannesburg Stock Exchange, Romanian Statistical Review, 2, 88-104.

11. Pan, Q., \& Pan, M. (2014). The Impact of Macro Factors on the Profitability of China's Commercial Banks in the Decade after WTO Accession, Open Journal of Social Sciences, 2, 64-69.

12. Quy, V.T., \& Loi, D.T.N. (2016). Macroeconomic factors and Stock Price - A Case Of Real Estate Stocks on Ho Chi Minh Stock Exchange, Journal of Science Ho Chi Minh City Open University, 2(18), 63-75.

13. Saeed, S., \& Akhter, N. (2012). Impact of Macroeconomic Factors on Banking Index in Pakistan, Interdisciplinary Journal of Contemporary Research in Business, 4(6), 1200-1218.

14. https://www.sbv.gov.vn

15. https://nif.mof.gov.vn 